\section{STEREOPHONIC RECORDINGS OF ENHANCED MUSIC}

$\mathrm{D}^{\mathrm{E}}$ MONSTRATIONS of the stereophonic reproduction of music and speech were given at the Carnegie Hall in New York City on April 9 and 10. This was the culmination of a long series of researches by Bell Telephone Laboratories. The first step in this achievement was demonstrated in 1933, when a symphony concert produced in PhiladeIphia was transmitted over telephone wires to Washington and there reproduced stereophonically and with enhancement before the National Academy of Sciences. Subsequent researches by Dr. H. Fletcher and his colleagues at the Bell Laboratories have supplied the equipment and technique for recording such a production on film.

With the co-operation of Leopold Stokowski and the Philadelphia Orchestra, the Tabernacle Choir and organists in Salt Lake City, and of Paul Robeson and other artists, their music and drama was recorded both in Philadelphia and in Salt Lake City. At a later audition, the director or artist was able to vary the recorded volume and to change the tonal colour of the music to suit his taste. He could soften it to the faintest pianissimo or amplify it to a volume ten times that of any orchestra without altering its tone quality, or he could augment or reduce the high or low pitches independently. While he was thus enhancing the music which he himself had directed, his interpretation was being re-recorded on film as a permanent record.

Selections for reproduction, chosen to demonstrate the full capabilities of this system, were given. From the choral numbers, vocal solos, organ, drums and grand opera reproduced at Carnegie Hall, the audience gained an idea of the versatility of the stereophonic system. A stirring climax for the programme was provided by the closing scene of the "Götterdämmerung". Dr. Stokowski took full advantage of the tenfold increase of sound over that of the largest orchestra, and effectively used the individual control to make the soloists' voice clearly heard above the orchestra. Dr. Stokowski has shown a full grasp of the possibilities of the new system.

In the New York World Telegraph of April 10, L. Biancolli describes a new effect demonstrated at Carnegie Hall. When the light werit out all that one saw was a gossamer veil hung across the stage, with a soft red glow playing on it. Then a flute sounded thinly from the distance; a crowd bellowed thunderously; horses galloped by ; thunder rumbled; a man talked as he walked from one end of the stage to the other. Then the whole width, breadth and depth of a symphony orchestra went into action. It sounded real, spread out in space. But it all came from a set of sound boxes and horns each functioning separately and in unison. "Dogged research in electricity, acoustics, dynamics had shown one more miracle-spread-out sound coming straight from the source, with no hint of crowding. Drums were at one end, flutes at another and in between other instruments were heard clearly across the stage. There was no blurring, no congestion. Pianissimi were the merest hush and fortissimi had the impact of a cannonade. The trick of giving orchestral music 'position' in recordings and weaving in nuances between nuances is now a perfected fact."

\section{APPOINTMENTS VACANT}

APPLICATIONS are invited for the following appointments on or before the dates mentioned:

Crvil EngInefRing Assistant--The Waterworks Engineer, Town Hall, Wakefield (August 8).

TEACHER OF MECHANICAL EngINEkRING at the Smethwick Municipal College-The Chief Education Officer, 215 High Street, Smethwick.

\section{REPORTS AND OTHER PUBLICATIONS}

(not included in the monthly Books Supplement) Great Britain and Ireland

Experimental and Research Station, Nursery and Market Garden Industries Development Society, Ltd., Cheshunt. Twenty-fifth Annual Report, 1939. Pp. 60. (Cheshunt: Nursery and Market
Garden Industries Development Society, Ltd.) Garden Industries Development Society, Ltd.)
Philosophical Transactions of the Royal Society of London. Series A : Mathematical and Physical Sciences. No. 799, Vol. 239: The Friction of Lubricated Metals. By F. P. Bowden and I. Leben. Pp. $27+5$ plates. $88.6 d$. Series B : Biological Sciences. No. 571, Vol. and Dr. T. S. Mestoll. Pp. 305-355. 88. (London: Cambridge University Press.)

\section{Other Countries}

Bulletin of the American Museum of Natura History. Vol. 77, Art. 2: A Supplement to the American Land and Fresh-Water Isopod Crustacea. By Willard G. Van Name. Pp. 109-142. (New York :
American Museum of Natural History.) Proceedings of the United States National Museum. Vol. 87, No. 3076: Catalog of Human Crania in the United States National Museum Collections-Indians of the Gulf States. By Ales Hrdlicka. Pp. 315-
464. (Washington, D.C. : Government Printing Office.) 464. (Washington, D.C. : Government Printing Office.)
Report for the Year 1939 of His Majesty's Astronomer at the Cape of Good Hope to the Secretary of the Admiralty. Pp. 10. (Cape of
Good Hope: Royal Observatory.)

Union of South Africa : Department of Agriculture and Forestry. nut or Njugo Bean. By J. M. Holm and Dr. B. W. Marloth. Pp. 10. nut or Njugo Bean. By J. M. Holm and Dr. B. W. Marloth. Pp. 10.
(Pretoria: Government Printer.) 3d. Survey of India. General Report 1939, from 1st October 1938 to 30th September 1939 . Pp. xii $+83+8$ plates +7 maps. (Calcutta : Survey of India.) $1 \cdot 8$ rupees; $28.6 d$.

Triennial Programme of Work for the Forest Research Institute, Dehra Dun, for 1939-42. Pp. 32. (New Delhi : Government of India
Press.)

Smithsonian Miscellaneous Collections. Vol. 99, No. 4: A CheckList of the Fossil Birds of North America. By Alexander Wetmore. (Publication 3587.) Pp. ii + 81. Vol. 99, No. 5: The 11-Year and 27-Day Solar Periods in Meteorology. By H. Helm Clayton. (Publication 3589.) Pp. $\mathrm{ii}+20$. (Washington, D.C.: Smithsonian Institu-

U.S. Department of Agriculture. Circular No. 568 : Factors Influencing the Use of some Common Insecticide-Dispersing Agents By Lynn H. Dawsey. Pp. 10. 5 cents. Yearbook Separate No. 1718 Feeding Requirements of Gallinaceous Upland Game Birds. By
Ralph B. Nestler. Pp. 893-924. (Washington, D.C.: Government Ralph B. Nestler. Pp. 893-924. (Washington, D.C. : Government
Printing Office.)

Y117

U.S. Department of the Interior: Office of Education. Know Your Timon Covert. Pp. iii +17. 5 cents. Pamphlet No. 89: Opportunities for the Preparation of Teachers in the use of Visual Aids in Instruction. By Katherine M. Cook and Florence B. Reynolds. Pp. iii +13.5 cents. Pamphlet No. 90: Opportunities for the Preparation of Teachers in Conservation Education. By Katherine M. Cook and Florence E. Reynolds. Pp. iii +13 . 5 cents. Vocational Division Bulletin No. 205 (Business Education Series No. 12): Co-operative Part-Time Retail Training Programs ; Supervision, Co-ordination and Teaching. By Kenneth B. Haas. Pp. vii +96. 15 cents. (Washington,
D.C. : Government Printing Office.) New York Zoological Society. Report of the Director of the New York Zoological Society. Report of the Director of the
Aquarium. Pp. 30. (New York: New York Zoological Society.) [117 Tanganyika Territory: Department of Tsetse Research. Tsetse Research Report, 1935-1938. Pp. 88. (Dar es Salaam : Government
Printer.) 58.

Some Problems of the New World Order. By Dr. G. H. Scholefleld
Cawthron Lecture, 1939.) Pp. 29. (Nelson: Cawthron Institute.) 1117 Trinity College Bulletin. Vol. 37, New Series, No. 2: A list of Books for a College Student's Reading. Edited by Prof. Harry Todd Costello. Third edition, rewritten. Pp. 125. (Hartford, Conn.:
Trinity College.)

University of Washington Publications in Anthropology. Vol. 8, No. 2: Coos Myth Texts. By Melville Jacobs. Pp. 127-260. (Seattle,

University of Illinois: Engineering Experiment Station. Bulletin No. 321: Summer Cooling in the Research Residence with a Condensing Unit operated at Two Capacities. By Prof. Alonzo P. Kratz, Prof. Seichi Konzo, Prof. Maurice K. Fahnestock and Edwin L. Broderick. Pp. 70, 70 cents. Bulletin No. 322: An Investigation of Rigid Frame Bridges, Part 3 : Tests of Structural Hinges of ReinIll. : University of nllinois.)
[157 